\title{
Economic Efficiency And Its Determinants In Chu-Mango Farming In The Mekong Delta, Vietnam
}

\author{
Truong Hong Vo Tuan Kiet ${ }^{1^{*}}$ \\ ${ }^{1}$ PhD student in Institute of Agricultural and Food Policy Studies, Putra University, Malaysia \\ ${ }^{1}$ Researcher in Mekong Delta Development Research Institute, Can Tho University, Vietnam \\ ${ }^{1}$ Scholar in SEARCA, Philippines *Corresponding author:thvtkiet@ctu.edu.vn
}

\author{
Shaufique F Sidique ${ }^{2}$ \\ ${ }^{2}$ Institute of Agricultural and Food Policy Studies, Putra University, Malaysia
}

\author{
Ahmad Hanis I A Hadi ${ }^{3}$ \\ ${ }^{3}$ Faculty of Agriculture, Putra University, Malaysia
}

Nguyen Thi Kim Thoa ${ }^{4}$

${ }^{4}$ Mekong Delta Development Research Institute, Can Tho University, Vietnam

\begin{abstract}
The paper employed a Cobb-Douglas stochastic frontier profit function to measure the level of economic efficiency (EE) and its determinants. The structured questionnaire was used to collect data from 522 of sampling observations $(212,171$, and 139 observations for seasons 1,2, and 3, respectively) randomly selected from designated locations in the Mekong Delta (MD). The study established a mean EE of 36.2\%,31.9\%, and 35.9\% in seasons 1, 2, and 3, respectively. The study identifiedthe land area and wrapping bag to be positively and significantly influencing on profit efficiency among three seasons. Besides, the results of the analysis indicated that labour price was important factor in season 3 at the 5\% significance level, and price of the root fertiliser, leaf fertiliser and labour affected mainly on profit efficiency in season 2 at the $1 \%$ significance level. By contrast, the variable of the fungicide price in season 2, and the root fertiliser price in season 3 were negative factors on profit efficiency at the $1 \%$ significance level. Particularly, policy solutions were recommended that farmers should design Chu-mango gardens with appropriate trees density as well as encourage gardeners to use bags for wrapping mango fruits in farming in order to increase profit efficiency. Specially, Chu-mango growers should be empowered in land area acquisition to applied advanced technology in large-scale production more effectively.
\end{abstract}

Keywords:

Chu-mango, economic efficiency, the Mekong Delta

Article Received: 18 October 2020, Revised: 3 November 2020, Accepted: 24 December 2020

\section{I.INTRODUCTION}

Mango ispopular tropical fruit in developing countries over the world, especially is in Asia. According to [1], Vietnam takes the $16^{\text {th }}, 7^{\text {th }}$ position in terms of mango volume in the world, and in Asia, respectively. In Southeast Asia, Vietnam ranks $3^{\text {rd }}$ in terms of mango volume after Thailand, Indonesia.

In Vietnam, mango has been grown in all provinces of the county with mango production volume about 815,200 tons, and mango production area approximately 104,000 ha in 2019, in which the MD has considered center for mango production in Vietnam. The MD has supplied to international and domestic markets about 511,800 tonsof fresh mango volume with production area nearly 48,200 ha in 2019[2]. There are many varieties of mango in the MD, Hoaloc-mango and Chu-mango are two delicious mango varieties and they are widely- 
knownconsumers.Chu-mango have a sweet taste, lots of water, thick flesh, yellow color and pleasant aroma. Chu-mango is an important fruit in Vietnam which is used popularly as a vitamin supply source. It is not only use as fresh fruits but also can be used under processing products as well.

In the view of [3], average cultivation of mango grower is small-scale nearly 0.7 hectares per farmer, and yearly average net income per household is VND 105 million $(\approx$ US\$4,900). This results in a fragmented production system that affects negatively on market information connection, technological application, and largescale production to fulfil requirements of market. It stems from weak collaboration of stakeholders via contract farming, especially is small farmers who are sensitive to market price dynamic.

The primary objective of this study was to measure the level of economic efficiency and its determinants in Chu-mango production in the MD using the stochastic frontier profit function approach. Evidence from this study is contribute to the current argument in finding ways of enhancing Chu-mango production in small-holder farming indeveloping countries by highlighting policy implications.The rest of the paper is structured as follows: the methodology is described in section 2, followed by the empirical results in section 3. Conclusions with findings and policy implications are presented in section 4 .

\section{METHODOLOGY}

\subsection{Sampling Techniques}

A multistage sampling technique was used to randomly select and collect primary data from Chu-mango growers. At the first stage, the study was conducted in the MD where isfamous for the cultivation of mango as well as is considered central mango production in Vietnam, as it accounts for $62.8 \%$ of the mango production volume and for $46.3 \%$ of the mango production area in Vietnam. At the second stage, the three selected provinces, namely, Dong Thap, An Giang, and Vinh Long because, combined, they account for approximately $62 \%$ of the mango production volume and $60 \%$ of the mango production volume area in the $\mathrm{MD}[2]$. Finally, a simple random sampling technique was used to select 522 sampling observations $(212,171$, and 139observations for seasons 1, 2, and 3, respectively).

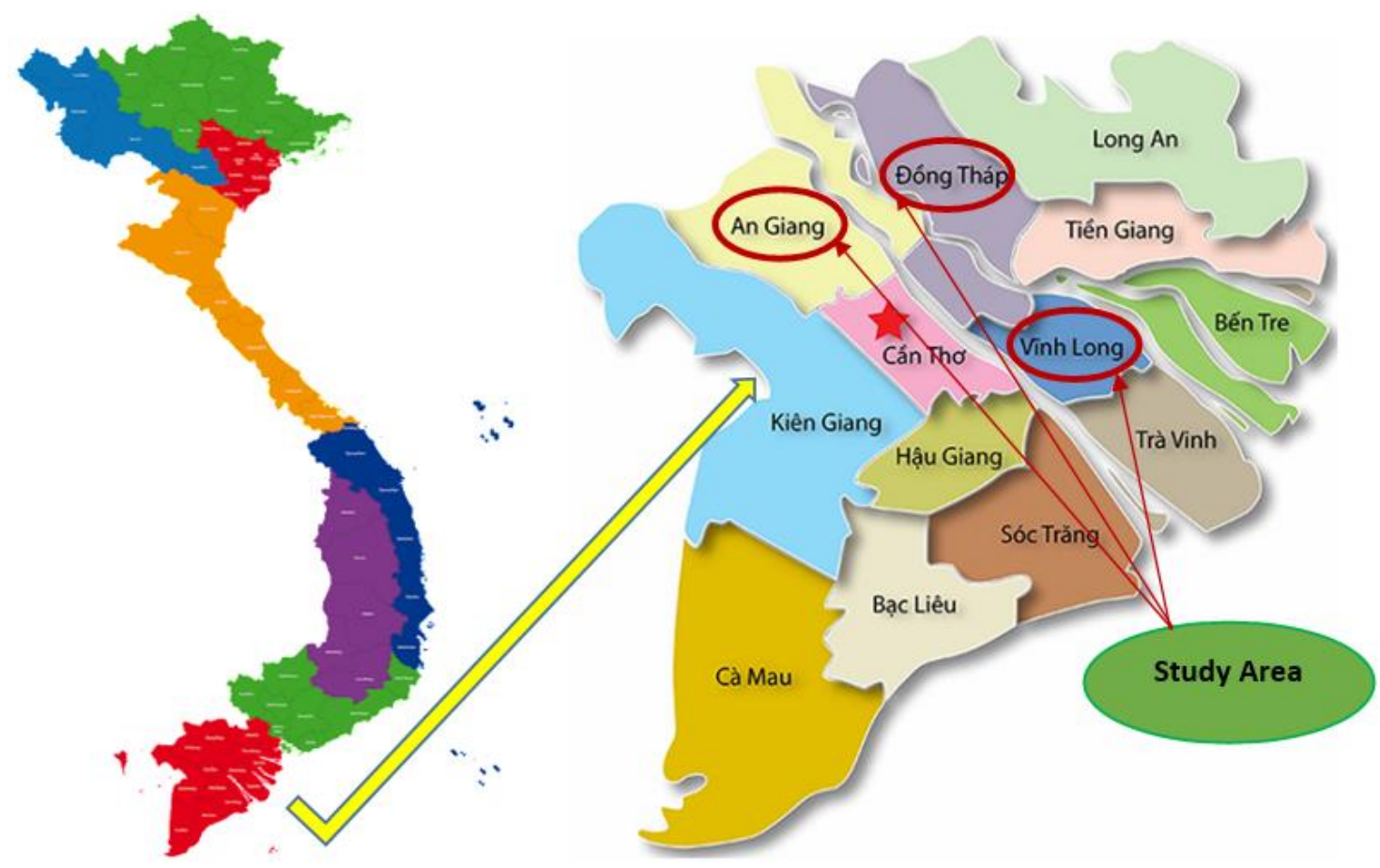

Figure 1. Study area in the Mekong Delta 


\subsection{Empirical Model}

For the objectives of the present paper, the underlying profit frontier functionis approximated by the Cobb-Douglas functional form to estimate the socio-economic characteristics and economic efficiencies respectively of the Chu-mango farmers.

The stochastic frontier profit function was defined by:

$\pi *=\frac{\pi}{\rho}=h(q i, z) \exp (v i-u i)$

Where: $\pi *=$ normalized profit of $\mathrm{i}$-th farmer; $\frac{\pi}{\rho}=$ description of the normalized profit, $q i=$ vector of variable inputs; $Z=$ vector of fixed input(s); $P=$ output price used to normalize variables in the model; $\pi=$ farmer's profit defined as total revenue minus total cost of production (here mango revenue consists of returns from the sales of mango output; while total cost was made up of the cost of fertiliser, labour and agrochemical); $\exp (v i-u i)=$ composite error term.

The economic efficiency (EE) of an individual farmer in the context of stochastic frontier profit function was derived as a ratio of the predicted, observed or actual profit ( $\pi i)$ to the corresponding predicted maximum profit ( $\pi i *$ ) for the best farm or frontier profit given the price of variable inputs and the level of fixed factor(s) of production of that farmer. Mathematically, it was expressed as following:

$$
\mathrm{EE}=\frac{\pi i}{\pi i *}=\frac{(q i, z) \exp (v i-u i)}{(q i, z) \exp (v i)}
$$

Then,

$$
\mathrm{EE}=\frac{\exp \left(v i-u_{i}\right)}{\exp (v i)}
$$

The stochastic disturbance term (ei) consisted of two independent elements: " $v$ " and " $u$ ". The symmetric two sided error term ( $v$ ) accounted for random variation in profit attributed to factors outside the farmer's control (random effects, measurement errors, omitted explanatory variables and statistical noise). The one-sided component (u) was a non-negative error term accounting for the inefficiency of the farm. Thus represented the profit shortfall from its maximum possible value that would be given by the stochastic profit frontier. However, when $u=0$, it implied farm profit lies on the efficiency frontier (i.e. $100 \%$ profit efficiency) and $u<0$ implied that the farm profit lied below the efficiency frontier. Both $v$ and $u$ were assumed to be independently and normally distributed with zero mean and constant variance [4].

A multiple regression model based on the stochastic frontier analysis (SFA) which assumed Cobb-Douglas functional form was employed to determine the profit efficiency of mango producers in the study area. The frontier model estimated following [4] was therefore specified as following:

$$
\ln \pi_{i}^{*}=\beta \mathrm{o}+\beta 1 \ln X^{*} 1+\beta 2 \ln X^{* 2}+\beta 3 \ln X^{*} 3+
$$

$\beta 4 \ln X^{*} 4+\beta 5 \ln X^{*} 5+\beta_{k} \ln X_{k}^{*}+V i-U i$

Where:

Ln = Natural logarithm,

$\pi_{i}^{*}=$ Normalized profit computed for i-th farmer,

$X_{1}^{*}=$ Price of pesticide (VND/litres)

normalized by price of mango,

$X_{2}^{*}=$ Price of fungicide (VND/litres)

normalized by price of mango,

$X_{3}^{*}=$ Price of root fertiliser $(\mathrm{VND} / \mathrm{kg})$

normalized by price of mango,

$X_{4}^{*}=$ Price of leaf fertiliser $(\mathrm{VND} / \mathrm{kg})$,

(spraying on mango leaves to stimulate mango flower) normalized by price of mango,

$X_{5}^{*}=$ Price of labour (VND/ man day)

normalized by price of mango,

$X_{k}=$ Area of land cultivated ( cong=1,000 $\mathrm{m}^{2}$ ),

$\beta_{0}, \beta_{1 \mathrm{~m} 5}$, and $\beta_{k}$ are parameters to be

estimated, represents statistical disturbance

term and $u_{i}=$ represents profit inefficiency

effects of $\mathrm{i}$-th farmer.

The determinants of profit inefficiency were modeled in terms of socio-economic variables of the Chu-mango growers and other factors. To achieve value of distribution parameter of economicinefficiency[5], the paper used the following equation:

$$
u_{i}=\alpha_{0}+\sum_{r=1}^{9} \alpha_{r} Z_{r}+\mathbf{k}
$$


Where:

$\boldsymbol{u}_{i}=$ economic inefficiency of $\mathrm{i}$-th farmer,

$\alpha_{0}$ and $\alpha_{r}=$ Parameters to be estimated,

$Z_{r}=$ Variables explaining inefficiency effects, $\mathrm{r}=1,2,3 \ldots, \mathrm{n}, \mathrm{k}$ is truncated random variable.

$Z_{1}=$ The age of farmer (year),

$Z_{2}=$ Farmers level of education (years spent in acquiring formal education)

$\mathrm{Z}_{3}=$ Farmer'sfarming experience (year)

$\mathrm{Z}_{4}=$ Dummy value of credit access (access

$=1$, no access $=0$ )

$\mathrm{Z}_{5}=$ Payment for agro-input wholesaler (ending of crop $=1$, payment immediately $=0$ )

$\mathrm{Z}_{6}=$ Dummy value of wrapping bag (wrap = 1 , no wrap =0) (applied mango wrap technique against incursion of pest, insect)

$\mathrm{Z}_{7}=$ Dummy value of market access (access = 1 , no access $=0$ )

$\mathrm{Z}_{8}=$ Dummy value of classifying sale (classification $=1$, no classification $=0$ ) (selling mango is classified including: first level with best price, second level with medium price, and third level with lowest price)

$\mathrm{Z}_{9}=$ Plant density (plants/ha)

For consistency purposes, the study used the maximum likelihood estimation (MLE) technique for estimating profit functions and inefficiency model parameters based on the FRONTIER 4.1 software program.

\section{EMPIRICAL RESULTS}

\subsection{Estimation Procedure}

At present, farmers in the MD have been producing mangoes actively year-round by implementing the flowering stimulation technique. This has resulted in mango harvesting taking place throughout the year as follows:

Natural season: flowering fromJanuary toFebruary, harvesting from mid-April tolate June. Early season: flowering fromNovember to December, harvesting from mid-February to April.

Off-season:flowering fromMay to June, harvesting from mid-August to October.

Late season: flowering from late August to October, harvesting fromlate November to February of the next year (this is known as the festival season because the harvesting time is focused on important festivals such as those that take place in mid-October and mid-January according to the lunar calendar (Buddhist days), Christmas, New Year, and Lunar New Year.

Table 1- Seasonal schedule of Chu-mango in the Mekong Delta

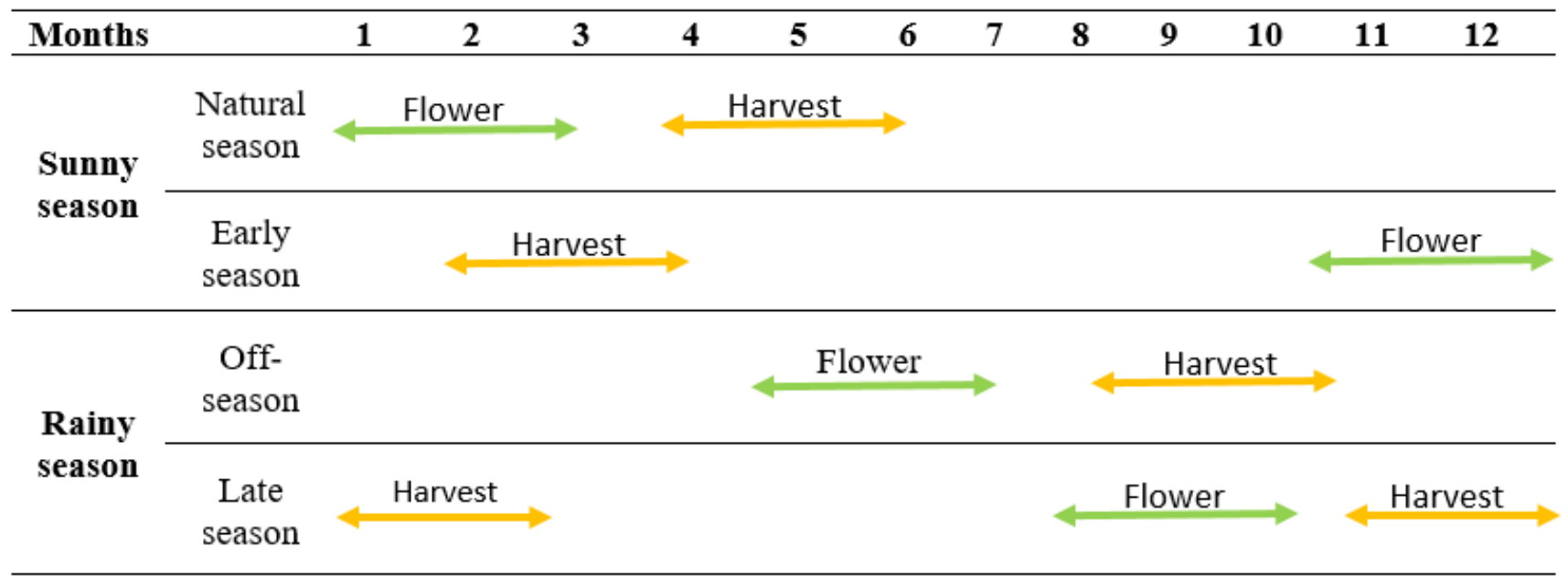

Source: Field Survey Data, 2018

Though mango producers in the MD can produce mangoes year-round (Table 1) by implementing the flowering stimulation technique off-season, they usually choose two or three (maximum) 
seasons per year based on the weather conditions in the MD, which has a sunny and a rainy season. The off-season (season 1) is considered to be the main mango production season in the MD because during this period the selling prices often higher than during the other seasons. The late season (festival season; season 2) is charaterised by high selling prices, there is tough competition between mango and different seasonal fruits during this period. Finally, the natural and early season of sunny season are collectively known as season 3, which takes place infavourable climate conditions. Hence, the production cost during this season differs from those of season 1 and season 2 .

Several hypotheses could be tested by usingthe generalised likelihood ratio (LR) test $=-2\{\log [\mathrm{L}$ (H0) - $\log [\mathrm{L}(\mathrm{H} 1)]\}$, in which L (H0) and L (H1) denote the values of the likelihood function under the null (H0) and the alternative (H1) hypothesis, respectively. LRhas approximately a chi-square distribution if the given null hypothesis is true with a degree of freedom equal to the number of parameters assumed to be zero in (H0). The first null hypothesis was the statement that the CobbDouglas profit function was the best fit for the data. The result indicated that the null hypothesis was not rejected in three cases because Lambda values $(\boldsymbol{\lambda} \mathbf{1}=24.72, \boldsymbol{\lambda} \mathbf{2}=-30.40, \boldsymbol{\lambda} \mathbf{3}=27.02)$ were less than critical value (32.67) at the 5\% significancelevel, thereby suggesting that theCobb-Douglas form was the best functional form for the data (Table 2). The Cobb-Douglas functional form of the stochastic frontier was employed in several previous studies because of its simplicity and appropriateness in computation and interpretation.

Table 2 - Generalised likelihood ratio test for stochastic profit model

\begin{tabular}{|l|l|c|c|c|r|r|l|}
\hline Season & \multicolumn{1}{|c|}{$\begin{array}{c}\text { Null } \\
\text { Hypotheses }\end{array}$} & $\begin{array}{c}\text { Log } \\
\text { likelihood } \\
\left(\mathbf{H}_{\mathbf{0}}\right)\end{array}$ & $\begin{array}{c}\text { Log } \\
\text { likelihood } \\
\left(\mathbf{H}_{\mathbf{1}}\right)\end{array}$ & $\begin{array}{c}\text { Test } \\
\text { statistic } \\
(\boldsymbol{\lambda})\end{array}$ & $\begin{array}{c}\text { Degree } \\
\text { of } \\
\text { Freedom }\end{array}$ & $\begin{array}{c}\text { Critical } \\
\text { value } \\
\mathbf{( 5 \% )}\end{array}$ & \multicolumn{2}{|c|}{ Decision } \\
\hline Season 1 & $\begin{array}{l}\text { Cobb-Douglas } \\
\text { was the best fit }\end{array}$ & -384.12 & -371.76 & 24.72 & 21 & 32.67 & Not rejected \\
\hline Season 2 & $\begin{array}{l}\text { Cobb-Douglas } \\
\text { was the best fit }\end{array}$ & -322.16 & -337.36 & -30.40 & 21 & 32.67 & Not rejected \\
\hline Season 3 & $\begin{array}{l}\text { Cobb-Douglas } \\
\text { was the best fit }\end{array}$ & -255.02 & -241.51 & 27.02 & 21 & 32.67 & Not rejected \\
\hline
\end{tabular}

* Critical values with asterisk are taken from Kodde and Palm (1986). For these variables the statistic $\lambda$ is distributed following a mixed $\chi 2$ distribution

Table 3 shows that the maximum likelihood estimates of the profit frontier for Chu-mango growers in the MD. The sigma squares $\left(\sigma^{2}\right)$ of Chu-mango gardeners in the MD were 64.51, 85.39, and 29.87 in seasons 1, 2, and 3, respectively. All sigma squares were significantly different from zero, which suggested a good fit of the models and the correctness of the specified distributional assumptions.Moreover, the gamma parameters $\quad\left(\gamma_{1}=0.9987, \gamma_{2}=0.9999, \gamma_{3}=0.9977\right)$ were quite high at the $1 \%$ of probability level, thereby implying that more than $99 \%$ of the variation in seasons 1,2 , and 3 resulted from the profit efficiency of the sampled farmers rather than from random variability.

Table 3- MLE estimates for SFA model of Chu-mango in the MekongDelta

\begin{tabular}{|l|c|c|c|c|c|c|}
\hline \multirow{2}{*}{ Variables } & \multicolumn{2}{|c|}{ Season 1 } & \multicolumn{2}{c|}{ Season 2 } & \multicolumn{2}{c|}{ Season 3 } \\
\cline { 2 - 6 } & Coef & SE & Coef & SE & Coef & SE \\
\hline Dependent Variable: Ln profit(VND)
\end{tabular}




\begin{tabular}{|c|c|c|c|c|c|c|}
\hline Constant & $7.298^{* * *}$ & 0.8094 & $8.580^{* * * *}$ & 0.0689 & $5.682^{* * * *}$ & 0.5653 \\
\hline$\left(\mathrm{X}_{1}\right)$ Ln pesticide price (VND/litres) & -0.0179 & 0.0888 & $0.0146^{* * *}$ & 0.0043 & -0.0119 & 0.0789 \\
\hline$\left(\mathrm{X}_{2}\right)$ Ln fungicide price (VND/litres) & 0.0331 & 0.1603 & $-0.2791^{* * *}$ & 0.0061 & 0.0223 & 0.2261 \\
\hline$\left(\mathrm{X}_{3}\right) \mathrm{Ln}$ root fertiliser price $(\mathrm{VND} / \mathrm{kg})$ & 0.0365 & 0.1900 & $0.7004^{* * *}$ & 0.0158 & $-0.9067^{* * *}$ & 0.1443 \\
\hline$\left(\mathrm{X}_{4}\right)$ Ln leaf fertiliserprice $(\mathrm{VND} / \mathrm{kg})$ & -0.0679 & 0.0873 & $0.646^{* * *}$ & 0.0059 & 0.1477 & 0.1237 \\
\hline$\left(\mathrm{X}_{5}\right)$ Ln labour price $(\mathrm{VND} /$ day) & 0.1400 & 0.3210 & $0.1139^{* * *}$ & 0.322 & $0.4879^{* *}$ & 0.2556 \\
\hline$\left(\mathrm{X}_{6}\right) \mathrm{Ln}$ land area $\left(\mathrm{cong}=1,000 \mathrm{~m}^{2}\right)$ & $0.9053^{* * *}$ & 0.0863 & $0.6365^{* * *}$ & 0.0091 & $0.9706^{* * *}$ & 0.1101 \\
\hline \multicolumn{7}{|l|}{ Diagnostic Statistics } \\
\hline Sigma square $\left(\sigma^{2}\right)$ & $64.51^{* * *}$ & 22.59 & $85.39^{* *}$ & 38.57 & $29.87^{* * *}$ & 7.621 \\
\hline Gamma $(\gamma)$ & $0.9987^{* * *}$ & 0.0007 & $0.9999^{* * *}$ & 0.0000 & $0.9977^{* * *}$ & 0.0015 \\
\hline Log-likelihood function & -384.12 & & -322.16 & & -255.02 & \\
\hline Observations $(\mathrm{N})$ & 212 & & 171 & & 139 & \\
\hline
\end{tabular}

Source: Field Survey Data, 2018

* Significant at $10 \%$ level, ** significant at 5\% level, *** significant at $1 \%$ level

Table 3 gives summary statistics of various variables used in stochastic frontierprofit function analysis of Chu-mango farming in the MD by themaximum likelihood estimates (MLE)as follows:

In season 1, the estimated model revealed that the coefficient of the land area was positive and statistically significant at the $1 \%$ level. The positive relationship with profit conformed to a priori expectation suggesting that a $10 \%$ will increase in land area will result to a $9.053 \%$ rise in profit. This meant that there was scope for increasing profit by expanding land area. It pointed out the fact that Chu-mango farmers were operating at small scale level, therefore increasing their cultivated land area will improve profit as other things being equal.This implied growers with large land area hadmore incentive and resources to use effectively such aslabour and technology compare with small-scale growers.

Regarding season 2, the results also presented that the coefficients of the explanatory variables of the price of pesticide, root fertiliser, leaf fertiliser, labour and land area in the stochastic profit function were positively significant at the $1 \%$ level while the variable of fungicide price was negatively significant at the $1 \%$ level. Alternatively, a $10 \%$ increase in price of the pesticide, root fertiliser, leaffertiliser, labour and land area would result in about $0.146 \%, 7.00 \%$,
$6.46 \%, 1.139 \%$, and $6.365 \%$ increase in profit, whilst a $10 \%$ rise of fungicide price will lead to $2.791 \%$ decrease in profit of Chu-mango growers.

Turning to season 3 , the labour price was positive with coefficient of 0.4879 at the $5 \%$ significancelevel, thereby implyingthat an increase of the variable in production improved profit efficiency of Chu-mango farmers. The positive coefficient was in agreement with the expected sign and implied that as the amount of the labour price increases, profit also increases. This suggested that the available labour was efficiently managed along with other inputs to avoid redundancy and diminishing return to labour. Furthermore, the positively signed and significant coefficient of the land area at the $1 \%$ significance level showed that a $10 \%$ increase in cultivated land area will lead to $9.706 \%$ increase in profit obtained from the production of Chumango. By contrast, profit of $\mathrm{Chu}$ - mango was negative relationship with the rootfertiliser price in the model at the $1 \%$ significance level, thereby showing that a $10 \%$ increase in the price incurred through the root fertiliser purchase, the profit obtained from the mango production will decrease by $9.067 \%$.

\subsection{EconomicInefficiencyFunction}

The parameter estimates of the influence of farmer's socio-economic environment on economic efficiency are presented in Table 4. The 
results of the explanatory variables in the analysis of productive efficiency for Chu-mango production were computed by the MLE model.
These estimated coefficients are important implications to improve the economic efficiency of Chu-mango producers.

Table 4 - MLE of the determinants of economic inefficiency score

\begin{tabular}{|l|r|r|r|r|r|r|}
\hline \multirow{2}{*}{ Variable } & \multicolumn{2}{|c|}{ Season 1 } & \multicolumn{2}{c|}{ Season 2 } & \multicolumn{2}{c|}{ Season 3 } \\
\cline { 2 - 7 } & Coefficient & \multicolumn{1}{c|}{ SE } & \multicolumn{1}{c|}{ Coefficient } & \multicolumn{1}{c|}{ SE } & \multicolumn{1}{c|}{ Coefficient } & \multicolumn{1}{c|}{ SE } \\
\hline Constant & $-15.05^{* *}$ & 7.309 & $-54.73^{* *}$ & 28.21 & -0.5503 & 1.035 \\
\hline Age (Z1) & $0.0553^{*}$ & 0.0385 & $0.3058^{* *}$ & 0.1698 & $-0.2015^{* * *}$ & 0.0783 \\
\hline Education (Z2) & $0.3943^{* *}$ & 0.2035 & $1.726^{* *}$ & 0.7960 & $0.8071^{* * *}$ & 0.2611 \\
\hline Farming experience (Z3) & -0.0067 & 0.0907 & $0.4748^{* *}$ & 0.2611 & $0.2723^{* *}$ & 0.1332 \\
\hline Credit access (Z4) & $2.841^{* *}$ & 1.251 & $-5.163^{* *}$ & 2.789 & -0.0629 & 1.000 \\
\hline Payment for agro-input (Z5) & $-2.874^{* *}$ & 1.333 & $5.497^{* * *}$ & 2.137 & $3.597^{* * *}$ & 1.278 \\
\hline Wrapping bag (Z6) & $-21.36^{* * *}$ & 8.696 & $-30.04^{* * *}$ & 11.46 & $-4.203^{* *}$ & 2.130 \\
\hline Market access (Z7) & $16.58^{* *}$ & 7.311 & $21.80^{* * *}$ & 7.905 & $3.771^{* *}$ & 2.098 \\
\hline Classifying sale (Z8) & -1.476 & 1.182 & $-5.644^{* *}$ & 3.222 & -0.1537 & 1.021 \\
\hline Plant density (Z9) & $-0.0518^{* * *}$ & 0.0171 & $-0.0280^{* *}$ & 0.0132 & $-0.0445^{* * *}$ & 0.127 \\
\hline
\end{tabular}

Source: Field Survey Data, 2018

* Significant at $10 \%$ level, ** significant at 5\% level, *** significant at $1 \%$ level

Note: A negative sign of the parameters in the inefficiency function means that the associated variable has a positive effect on profit efficiency, and vice versa.

First, the parameters estimates pointed out that the classifying sale variable in second season was found positive and significant influence on farmers' economic efficiency at the $5 \%$ level. The positive sign of the classifying sale coefficient showed that if farmers sold Chu-mango following classifying form, profit could increase in $5.644 \%$ of season 2, thereby indicating that farmers who sold classified mangoes had higher profit than farmers who sold non-classified mangoes. This was festival season so buyers was willing to pay high price for classified Chu-mangoes that had well extrinsic and intrinsic attributes.

Second, the coefficient of the farming experience was negative and statistical meaning both seasons 2 , and 3 at $5 \%$ probabilitylevel. The result of the analysis indicated that the variable had a negative impact on profit efficiency among the growers sampled. The result wascontrary to the findings of [6], [7], which suggested a positive relationship between profit efficiency and farming experience. Third, the credit access variable was negative coefficient with profit efficiency at the $5 \%$ level in season 1. Similar finding was obtained by [8], thereby implying that receiving credit decreased farmers' profit efficiency. On the other hand, it was the positive and highly significant variable at the 5\% level in season 2, which implied farmer who had credit access was more economically efficient than farmer who did not have. The finding was consistent with those of other studies[6], [7].

Furthermore, the parameters estimates as seen in the Table 4 consisting of the payment for agroinput wholesaleron ending of harvest season was positive at the 5\% significance level in season 1 , and negative at the $1 \%$ level in seasons 2 , and 3 . Besides, the age variable was identified negative coefficient in seasons 1 , and 2 at the $10 \%$, and $5 \%$ significance levels, respectively, and positive coefficient in season 3 at the $1 \%$ significance level. For finding of the age variable in seasons 1 , and 2, these results corroborate those of [6], [8-11] who stated that farmers were older, they were difficult to apply the available technology and had a negative effect on profit efficiency. However, 
this went against the finding of the age variable in season 3 , implying a positive influence of age on economic efficiency of Chu-mango production. The similar result was obtained by [7], [9].

Particularly, the coefficient of plant density, and wrapping bag were positive and significant effect on profit efficiency among three seasons at the conventionalsignificance levels. . The positive sign of the wrapping bag variable indicated that if farmers use bags to wrap mangoes in production, their profit could increase. The main reason for this is that farmers focused on quality rather than quantity and they only wrapped high quality mango fruits, while also securing low wrapping bag costs, thereby achieving high selling prices. Meanwhile, the education, and market access variables were negative coefficients at the conventionalsignificance levels among three seasons. Educational level showed a negative impact on profit of Chu-mango farmers, meaning lack of education might not be considered as an element causing economic inefficiency. The research was in disagreement with some earlier studies [7], [8], [12] who found a statistical significant correlation between education and profit efficiency.

\subsection{Economic Efficiency Distribution}

The EE distribution scores (Table 5) indicated thatChu-mango farmers achieved on the average $36.2 \%, 31.9 \%$, and $35.9 \%$ level of profit efficiency in seasons 1,2 , and 3, respectively. It meantEE gap of about $63.8 \%, 68.1 \%$, and $64.1 \%$ in seasons 1,2 , and 3 , respectively. This suggested that the average farmer in the study area could increase profit by approximately $63.8 \%$, $68.1 \%$, and $64.1 \%$ in seasons 1,2 , and 3, respectively, by improving their economic efficiency.

Table 5 - Efficiency level distribution of EE scores

\begin{tabular}{|c|c|c|c|c|c|c|}
\hline \multirow{2}{*}{$\begin{array}{c}\text { Economic efficiency } \\
\text { level }\end{array}$} & \multicolumn{2}{|c|}{ Season 1} & \multicolumn{2}{|c|}{ Season 2} & \multicolumn{2}{|c|}{ Season 3} \\
\hline & Frequency & Percentage & Frequency & Percentage & Frequency & Percentage \\
\hline$<0.1$ & 51 & 24.06 & 50 & 29.24 & 27 & 19.42 \\
\hline $0.1-<0.2$ & 29 & 13.68 & 24 & 14.04 & 18 & 12.95 \\
\hline $0.2-<0.3$ & 18 & 8.49 & 16 & 9.36 & 19 & 13.67 \\
\hline $0.3-<0.4$ & 16 & 7.55 & 26 & 15.20 & 16 & 11.51 \\
\hline $0.4-<0.5$ & 28 & 13.21 & 15 & 8.77 & 19 & 13.67 \\
\hline $0.5-<0.6$ & 20 & 9.43 & 6 & 3.51 & 8 & 5.76 \\
\hline $0.6-<0.7$ & 18 & 8.49 & 12 & 7.02 & 6 & 4.32 \\
\hline $0.7-<0.8$ & 15 & 7.08 & 8 & 4.68 & 18 & 12.95 \\
\hline $0.8-<0.9$ & 16 & 7.55 & 5 & 2.92 & 7 & 5.04 \\
\hline $0.9-<1.0$ & 1 & 0.47 & 9 & 5.26 & 1 & 0.72 \\
\hline 1.0 & 0 & 0.00 & 0 & 0.00 & 0 & 0.00 \\
\hline Total & & 212 & & 171 & & 139 \\
\hline Mean & & 0.362 & & 0.319 & & 0.359 \\
\hline Std. deviation & & 0.270 & & 0.285 & & 0.269 \\
\hline Minimum & & 0.000 & & 0.000 & & 0.000 \\
\hline Maximum & & 0.900 & & 0.997 & & 0.901 \\
\hline
\end{tabular}

Source: Field Survey Data, 2018

The findings showed that the EE ranged from 0.00-0.90 in seasons 1 , and 3, and from 0.00-0.99 in season 2. The averageEE was 0.36 in seasons 1 , and 3 , and 0.32 in season 2. The implications of the result wasif the average Chu-mango farmer in the sample area was to obtain EE level of its most efficient counterpart, then the average farmer could experience a cost saving of $60.0 \%((1-$ 
$\left.0.36 / 0.90)^{*} 100\right)$ in seasons 1 , and 3, and $67.68 \%$ $\left((1-0.32 / 0.99)^{*} 100\right)$ in season 2 whereas the most inefficientgrower proposed a gain in $\mathrm{EE}$ of $100 \%((1-0.00 / 0.90) * 100)$ in seasons 1 , and 3, and $100 \%((1-0.00 / 0.99) * 100)$ in season 2 .

\section{CONCLUSIONS}

Evidence from this study suggests thatEEin season 1 ranked first in terms of profit efficiency approximately $36.2 \%$, followed by season 3 about $35.9 \%$ and then season 2 approximately $31.9 \%$. Adjustments in the input factors could lead to improveprofit of Chu-mango gardeners in the MD. More specific, the inputs that were important in determining output in season 1 was the land area, in season 2 wasthe pesticide price, fungicide price, root fertiliser price, leaf fertiliser price, labour price, land area, and in season 3 was the pesticide price, root fertiliser price, labour price and land area.

Given the empirical evidence in this study, the positive determinants of profit efficiency were the payment for agro-input wholesale on ending of season, wrapping bag and plant density in season 1 , credit access, wrapping bag, classifying sale and plant density in season 2, and the age, wrapping bag and plant density in season 3. On the other hand, the constraints to profit efficiency of Chu-mango producers were the age, education, credit access, market access in season 1, the age, education, farming experience, payment for input wholesale on ending of season and market access in season 2, the education, farming experience, payment for agro-input wholesale on ending of season, and market access in season 3.

A few comments on this research are important. Based on these findings, policy makers should focuson effective inputs modelsthat would boost profit efficiency through conducting regular workshops and orchard demonstrations on using input materials effectively. Also, farmers should design Chu-mango gardens with appropriate trees density as well as encourage gardeners to use bags for wrapping mango fruits in farming in order to increase profit efficiency. Specially, Chu-mango growers should be empowered in land area acquisition to applied advanced technology in large-scale production more effectively.

The Chu-mango fruit is not only an important nutrition source, but also a crucial income source of mango growers in the MD, Vietnam. Therefore, studies that help educate the role of EE contribute significantly to the identification of profit constraints. This knowledge helps policy and decision makers associated with the farming practice to improve mango season's year. A difference between this study and others on tropical fruits, was that analysed the EE of farmers three various seasons instead of only during one or throughout an entire year. Our study is fundamental when it comes to analysing the farming season division of tropical fruit in the MD, Vietnam. Further, it will play an important role in expand research on the EE of other tropical fruit throughout different seasons of the year.

\section{REFERENCES}

[1] F.A.O. (Food and Agriculture Organization), "Major tropical fruits Statistical compendium 2018," Rome, 2019.

[2] G.S.O (General statistic office of Vietnam), "Statistical YearBook 2019, 'Hanoi city, Vietnam, Publisher: Statistical Publishing House, 2020.

[3] S. William, "Business engagement in smallholder agriculture: Developing the mango sector in Dong Thap province," Shaping policy for development. Overseas Development Institute, 2014.

[4] A.B. Sunday, O.E. Uwemedimo, J.N. Elizabeth, N.K. Kesit, J.E. Daniel, and I. Akwa, "Economic efficiency of Cassava based farmers in Southern Wetland Region of Cross River State, Nigeria: A translog model approach,"International Journal of Humanities and Social Science, 3, 173181, 2013.

[5] L.T. Ogunniyi,"Profit efficiency among maize producers in Oyo State, Nigeria,"ARPN Journal of Agricultural 
and Biological Science, vol 6, pp. 11-17, 2011.

[6] H. Khan, and F.Ali,"Measurement of productive efficiency of tomato growers in Peshawar, Pakistan," (AGRIC. ECON. CZECH), vol 8, pp. 381-388, 2013.

[7] A.C. Mwita,"Assessment of profit efficiency among sweet yellow passion fruit farmers in Mbeere south, Embu country," Master of Science (Agribusiness management and trade), Kenyatta University, 2016.

[8] H.G. Daniel,"Analysis of economic efficiency in potato production: The case of smallholder farmers in Welmera district, Oromia special zone, Oromia, Ethiopia," M.A thesis in development economics. Department of econmics, College of business and economics, School of graduate studies, Hawassa University, 2016.

[9] R.S.M. Abdur, "A study on economic efficiency and sustainability of wheat production in selected areas of Dinajpur district," M. Sc Thesis. Bangladesh Agricultural University, 2012.

[10] A. Alam, H. Kobayashi, I. Motsumura, A. Ishida,and M. Esham,"Technical efficiency and its determinants in potato production: evidence from northern areas in Gilgit-Baltistan region",International journal of research in management, economics and commerce, vol 2,pp.1-17, 2012.

[11] T. Bealu, G. Endrias, andA.Tadesse, "Factors affecting economic efficiency in maize production: The case of Boricha Woreda in Sidama zone, southern Ethiopia," The fourth regional conference of the southern nationalities state economic development in Hawassa, 28p, 2013.

[12] H. Khan, and H. Saeed,"Measurement of technical, allocative and economic efficiency of tomato farms in Northern Pakistan," International conference on management, economics and social sciences, ICMESS'2011, Bangkok,2011. 